\title{
Seasonal distribution of ozone and its precursors over the tropical Indian region using regional chemistry-transport model
}

\author{
Sompriti Roy, ${ }^{1}$ Gufran Beig, ${ }^{1}$ and Daniela Jacob ${ }^{2}$ \\ Received 14 December 2007; revised 3 April 2008; accepted 5 August 2008; published 8 November 2008.
}

[1] An off-line regional chemistry-transport model (REMO-CTM) has been applied for the first time to the Indian geographical region to simulate the distribution of ozone and its precursors at the boundary level. The model accounts for the winds from ECMWF as lateral boundaries and latest emission inventories of the ozone precursors for the year 2003. An attempt has been made to validate the model with meteorological parameters like precipitation data and wind fields available from observations, satellite data for $\mathrm{CO}$, and that of surface ozone observations over different parts of India. Model results reproduce the precipitation pattern reasonably well. The qualitative agreement of model and ozone data is also found to be reasonable. Present results are also compared with the global chemistry transport model. The seasonal distribution of ozone and its precursors over the Indian region indicates a differential pattern driven by the spatial synoptic weather condition and local emissions. The continental tropical convergence zone (CTCZ) and long-range/regional transport also play an important role, especially over the IndoGangetic plains where the ozone, $\mathrm{CO}$, and $\mathrm{NO}_{\mathrm{x}}$ concentrations are found to be higher as compared to other parts of India.

Citation: Roy, S., G. Beig, and D. Jacob (2008), Seasonal distribution of ozone and its precursors over the tropical Indian region using regional chemistry-transport model, J. Geophys. Res., 113, D21307, doi:10.1029/2007JD009712.

\section{Introduction}

[2] Tropospheric ozone is either photochemically produced within the troposphere or transported from the stratosphere. In the troposphere, ozone is produced from the photochemical reactions of nitrogen oxides $\left(\mathrm{NO}_{\mathrm{x}}\right)$ and volatile organic compounds (VOCs) under sunlight. Tropospheric ozone is considered as a primary photochemical oxidant that could ultimately determine the oxidizing capacity of the atmosphere through its photolysis to $\mathrm{O}^{1}(\mathrm{D})$, which reacts with $\mathrm{H}_{2} \mathrm{O}$ to produce $\mathrm{OH}$ radicals. Since the amount of tropospheric ozone generated by photochemical reaction of chemical pollutants is much larger than the influx from the stratosphere, the concentrations and distributions of ozone are strongly affected by human activities. In the past few years India has experienced rapid industrialization and increase of population. So the anthropogenic emissions from fossil-fuel combustion have increased significantly in this period. Increasing anthropogenic emissions of $\mathrm{NO}_{\mathrm{x}}$, hydrocarbons and $\mathrm{CO}$ can cause a substantial increase in tropospheric ozone over India which can adversely affect the regional air quality and associated climate change.

[3] To study the distributions of ozone and its precursors over India the lack of sufficient observational data over the

\footnotetext{
${ }^{1}$ Physical Meteorology and Aerology Division, Indian Institute of Tropical Meteorology, Pune, India.

${ }^{2}$ Regional Climate Modeling Group, Atmosphere in the Earth System, Max-Planck-Institute for Meteorology, Hamburg, Germany.

Copyright 2008 by the American Geophysical Union. 0148-0227/08/2007JD009712\$09.00
}

Indian region poses a limitation. Nevertheless, some observational studies have been reported in the literature at scattered places over India [Khemani et al., 1995; Lal et al., 2000; Naja and Lal, 2002; Naja et al., 2003; Ahammed et al., 2006; Singh et al., 2008]. However, simultaneous measurements of ozone along with its precursors are sparse and only a few results are available [Naja et al., 2003; Beig et al., 2007]. A comprehensive field campaign namely Indian Ocean Experiment (INDOEX) was carried out during 1996-1999 mainly to study the pollution haze over the Arabian Sea and the Indian Ocean as a result of transport of pollutants from the Indian subcontinent [Ramanathan et al., 2001]. During INDOEX period, measurements of aerosols and trace gases over the Indian ocean region have also been made [Saraf et al., 2003]. During this campaign, the ozonesonde measurements which covered the region from $11.3^{\circ} \mathrm{N}$ to $20.2^{\circ} \mathrm{S}$ and from $62.3^{\circ} \mathrm{E}$ to $75.8^{\circ} \mathrm{E}$, revealed surface ozone values of the order of $20-50 \mathrm{ppb}$ over the oceanic region. The general trend of increasing surface ozone and $\mathrm{CO}$ values toward the continent was seen in the modeled as well as the observed mixing ratios [Saraf et al., 2003]. The measurements made over the Indian ocean have also shown transport of pollutants from Indian subcontinent to the Arabian Sea and Indian Ocean [Lelieveld et al., 2001]. Elevated ozone levels (60-70 ppbv) were observed in a remote marine environment over the Arabian Sea during INDOEX 1999. However, this program focused mainly on aerosols and transport of pollutants from continent to Indian Ocean region.

[4] In the past, several global models have been used to simulate the precipitation and other meteorological param- 
eters but how the synoptic weather conditions mixed with emissions of chemical compound influence the tropospheric ozone and related tracers is not adequately explored, especially over the Indian geographical region. Recent studies [Beig and Brasseur, 2006] using global model of ozone and related tracers (MOZART) over the Indian region have examined the changes in tropospheric ozone and its precursors that have occurred during the 1990s in the geographical region of India in response to enhanced human activities. The maximum variation in ozone concentration near the surface is found to be around 5-10 ppbv. Other studies involving global chemical transport models [Prather et al., 2003; Brasseur et al., 2006] suggest that surface ozone concentration could increase by as much as $25-$ $30 \mathrm{ppbv}$ in India between years 2000 and 2100, assuming an economic growth described by the IPCC/SRES A2 scenario. Other recent studies [Beig and Ali, 2006] using the global chemical model MOZART over the Indian region found that the Indo-Gangetic plains are highly susceptible to human induced emissions due to conducive synoptic weather pattern which make it a source region of ozone precursors within which these tracers remain confined and reinforce photochemical production of ozone. Some modeling studies that have assessed the trend in global tropospheric ozone and its precursors in response to changing emission loads [Prather et al., 2003; Saraf et al., 2003; Granier and Brasseur, 2003] have not discussed specifically the variations in the Indian tropical region which is emerging as one of the potential economic power likely to impact the global climate.

[5] However all of these studies were performed using global chemistry-transport models with coarser resolutions. This kind of simulation requires a realistic representation of the ozone- $\mathrm{NO}_{\mathrm{x}}$-hydrocarbon chemistry along with proper high-resolution emission inventory. A major source of uncertainty is the lack of systematic gridded inventory of ozone precursors. The lack of high-resolution regional chemical-transport model applied for this region is a limitation. Earlier, Mittal et al. [2007] have presented a gridded distribution of ozone and its precursors over the Indian region. However, the study was performed for few months (February-May 2000) using a global emission inventory. Moreover the study partially focuses on the impact of ozone levels on agriculture and human health. In the present paper, we made an attempt to simulate the distribution of ozone and its precursors near the boundary layer on a much finer resolution using regional chemistry-transport model focusing on the Indian tropical region with recently developed regional gridded emission inventory. In this study, we initially validate the model with observed meteorological -parameters and available observational data on chemical tracers and thereafter present the seasonal distribution of ozone, $\mathrm{CO}$ and $\mathrm{NO}_{\mathrm{x}}$ over India.

\section{Model Description}

[6] The regional model (REMO-CTM) is a three-dimensional, Eulerian hydrostatic model. In the current study REMO-CTM has been applied with the physical parameterization package of the global model ECHAM-4 [Jacob et al., 2001, 2007]. In the vertical a terrain following hybrid pressure-sigma coordinate is used and there are 20 levels of increasing thickness between the ground and 10 hpa pressure level. The horizontal resolution is 0.5 degree on a spherical rotated grid. The model domain is tropical India. The prognostic equations for surface pressure, temperature, specific humidity, cloud water and horizontal wind components are written in advective form on an Arakawa C-grid. It includes 63 compounds and 165 chemical reactions in the gas phase, aqueous phase chemistry and wet removal processes. For the time integration the leapfrog scheme with a time step of $5 \mathrm{~min}$ is applied. Further details of this model are available by Langmann [2000] with references therein.

[7] For this study, only the atmospheric part of the online model REMO was used to create meteorological fields to drive an off-line chemical model (REMO-CTM). This means that the online chemistry in REMO was not activated. REMO-CTM was initialized once and then run in climate mode for the year 2003, using ECMWF analyses at the lateral boundaries, which have been updated every $6 \mathrm{~h}$.

\section{Meteorological Data and Emissions}

[8] The chemistry model (REMO-CTM) is off-line and has a chemical part and a meteorological part and the chemical transport is driven by the output from the meteorological driver (REMO) typically once per hour. It considers surface emissions of several chemical compounds $\left(\mathrm{CO}, \mathrm{NO}_{\mathrm{x}}, \mathrm{VOC}\right.$, etc). The emissions for all the species apart from $\mathrm{CO}$ and $\mathrm{NO}_{\mathrm{x}}$, are taken from the Reanalysis of the Tropospheric chemical composition (RETRO) data which provide $0.5^{\circ} \times 0.5^{\circ}$ emission data set [Olivier et al., 2003]. The emissions for $\mathrm{CO}$ and $\mathrm{NO}_{\mathrm{x}}$ are taken from the recent high-resolution estimates of Indian national inventory, which account for the rapid temporal variability and small-scale geographical variations [Beig and Brasseur, 2006; Dalvi et al., 2006]. The emissions are further downscaled to $0.5^{\circ} \times 0.5^{\circ}$ using the GIS based statistical methodology [Dalvi et al., 2006] involving necessary activity data (S. K. Sahu and G. Beig, private communication, 2007). The total CO emission over the Indian region is considered to be $71420 \mathrm{Gg} / \mathrm{a}$ in the year 2003 of which biofuel sources (wood and cow dung burning) represents almost $50 \%$ of the total CO emissions in India. The total $\mathrm{NO}_{\mathrm{x}}$ emissions at surface over the Indian region have been estimated to be $4412 \mathrm{Gg} / \mathrm{a}$ for the year 2003. The maximum contribution to the $\mathrm{NO}_{\mathrm{x}}$ emissions is provided by coal which amounts to about $45 \%$ of the total $\mathrm{NO}_{\mathrm{x}}$ emissions over India. The second largest contributor to the $\mathrm{NO}_{\mathrm{x}}$ emissions is from fossil fuel combustions followed by biofuel and biomass burning which also contribute to $\mathrm{NO}_{\mathrm{x}}$ emissions. The VOC emissions of some of the organic compounds (e.g., $\mathrm{C}_{2} \mathrm{H}_{6}$ ) over the Indian region is $0.692 \mathrm{Gg} / \mathrm{a}$ in the year 2003 and is primarily contributed by the transport sector.

\section{Model Evaluation}

[9] In this section we compare the model results with observational data available from surface-monitoring sites and satellite data. We also compare our model results with the results obtained from the global model MOZART.

[10] Initially the model calculated meteorological parameters like total rainfall and pressure are compared with 

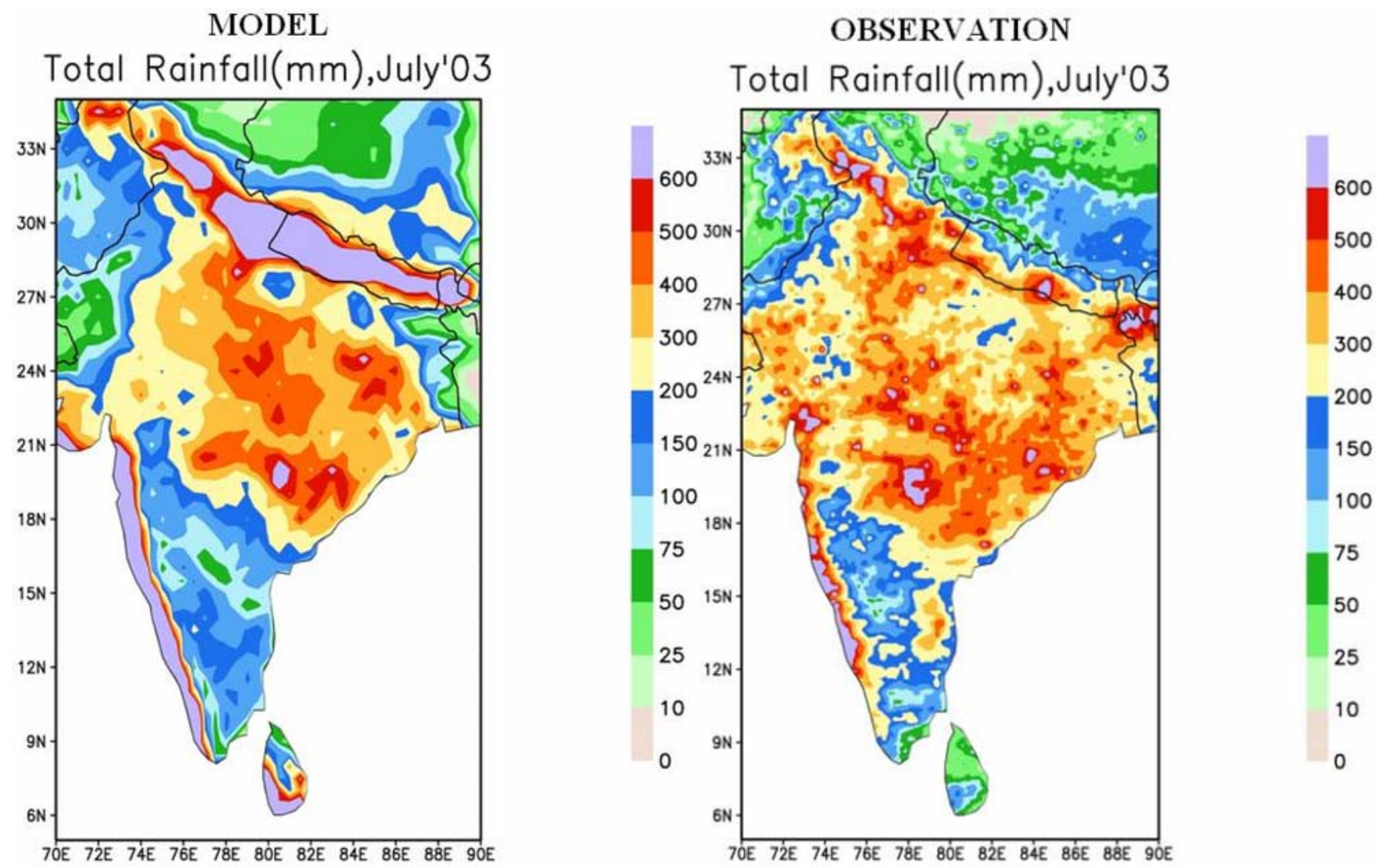

Figure 1. Comparison of total rainfall over India from model and observations (in millimeters) during the month of July 2003.

observed data for the year 2003. The total rainfall over India as simulated by the model during the month of July is compared with observations in Figure 1. The observational data are based on GOES Precipitation index (GPI), Special Sensor Microwave Imager (SSM/I), Advanced Microwave Sounding Unit (AMSU-B) and Global Telecommunications Station (GTS) data and is available from NOAA/Climate Prediction Centre (www.cpc.ncep.noaa.gov). In the year 2003, the southwest monsoon onset was on 8 June. During the month of June the rainfall in most parts of India was below $200 \mathrm{~mm}$ except in some regions over central, northeast and the coastal belt along the western side of India. The highest rainfall above $600 \mathrm{~mm}$ was observed in some parts of northeast India and along the west coastal belts over India. In Figure 1 we find that during the month of July the model predicted rainfall in most parts of the western coast is above $600 \mathrm{~mm}$ which matches well with observed data. The observed rainfall in major parts of India is in the range of 200-500 mm which the model reproduces well. Higher-rainfall belts in the range of $500-600 \mathrm{~mm}$ is observed over some parts of central, northern and eastern India and the simulated rainfall shows the same feature. Apart from the monsoon months of June, July, August and September the amount of rainfall is very less over the Indian region. The comparison of simulated rainfall with observations for these months was found to be satisfactory. In Figure $2 \mathrm{a}$ the calculated U-velocity over the Indian region is compared with the observed U-velocity obtained from NCEP Reanalyses (http://iridl.ldeo.columbia.edu/SOURCES/ .NOAA/.NCEP-NCAR) at around $1000 \mathrm{mb}$ for the month of May 2003. In Figure 2a we find that the simulated U-velocity in most parts of western and southwestern India is within the range of $2-8 \mathrm{~m} / \mathrm{s}$ which is also seen in the observed data. Also the U-velocity increases as we move toward the west coastal regions from the land areas. In some parts of eastern and northwestern India the predicted U-velocity is negative with an increase in magnitude as we move toward the boundaries. This feature is also seen in the observed U-velocity. In Figure $2 \mathrm{~b}$ the simulated V-velocity over the Indian region is compared with the observed V-velocity available from NCEP Reanalyses (http://iridl. ldeo.columbia.edu/SOURCES/.NOAA/.NCEP-NCAR) at around $1000 \mathrm{mb}$ for the month of May 2003. In Figure 2b we find that both the calculated as well as the observed $\mathrm{V}$-velocity is less than $-1 \mathrm{~m} / \mathrm{s}$ in many parts of central and southwestern India. Also it increases as we move from the landmasses toward the eastern coastal regions of India. In major portions of western India the simulated V-velocity lies in the range of $0-3 \mathrm{~m} / \mathrm{s}$. A similar feature is also seen in the observed data with the values being slightly lesser as compared to the simulated V-velocity.

[11] The simulated monthly mean concentrations of $\mathrm{CO}$ for the month of October at $850 \mathrm{hpa}$ is compared with satellite data obtained from Measurement of Pollution in the Troposphere (MOPITT) instrument in Figure 3. The data coverage of MOPITT is very poor near the surface and hence comparison is made at $850 \mathrm{mb}$ whose data coverage is relatively better. Over India, higher modeled concentrations in the range of $400-600 \mathrm{ppb}$ are located on the IndoGangetic regions showing the effect of biomass burning due 
MODEL

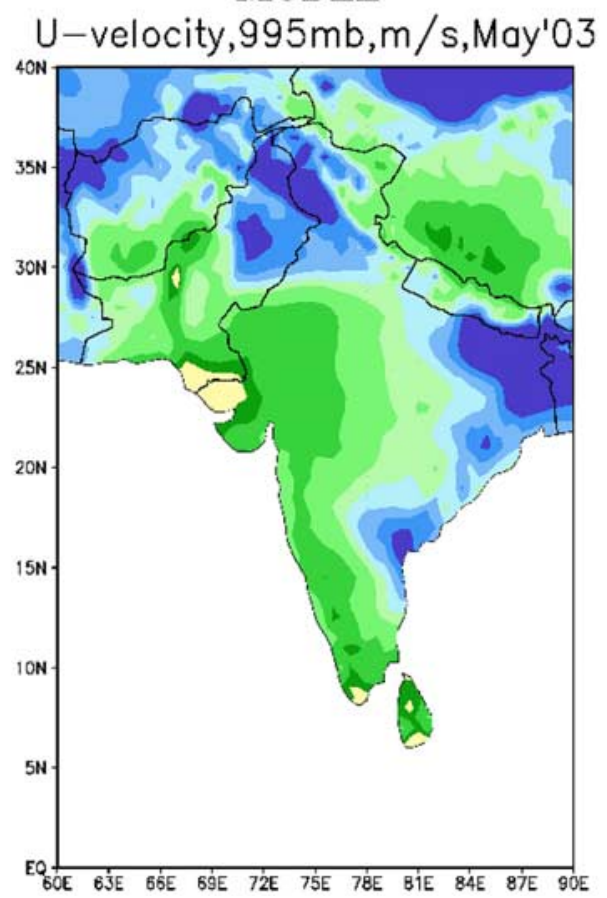

OBSERVATION

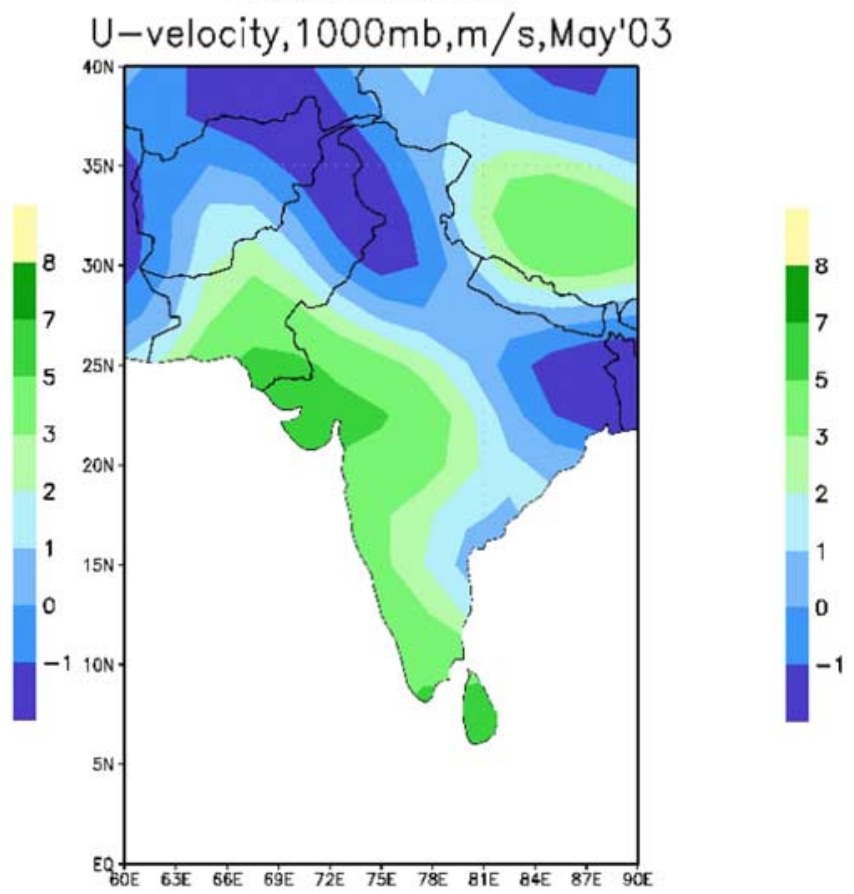

Figure 2a. Comparison of U-velocity over India from model and observations (in $\mathrm{m} / \mathrm{s}$ ) during the month of May 2003.

to extensive rural population in this area. In Figure 3, for monthly mean concentration of $\mathrm{CO}$ from satellite data, a similar feature is observed although the values are underestimated and the positions of the maximum concentrations of $\mathrm{CO}$ do not exactly match with the model simulated values. The concentrations of $\mathrm{CO}$ as obtained from satellite data are seen to be higher in parts of southwest India where emissions from the industrialized belts are more and the model reproduces this well. During the month of October the wind pattern is northeasterly over the Indian region.
MODEL

V-velocity, $995 \mathrm{mb}, \mathrm{m} / \mathrm{sec}, \mathrm{May}^{\prime} 03$

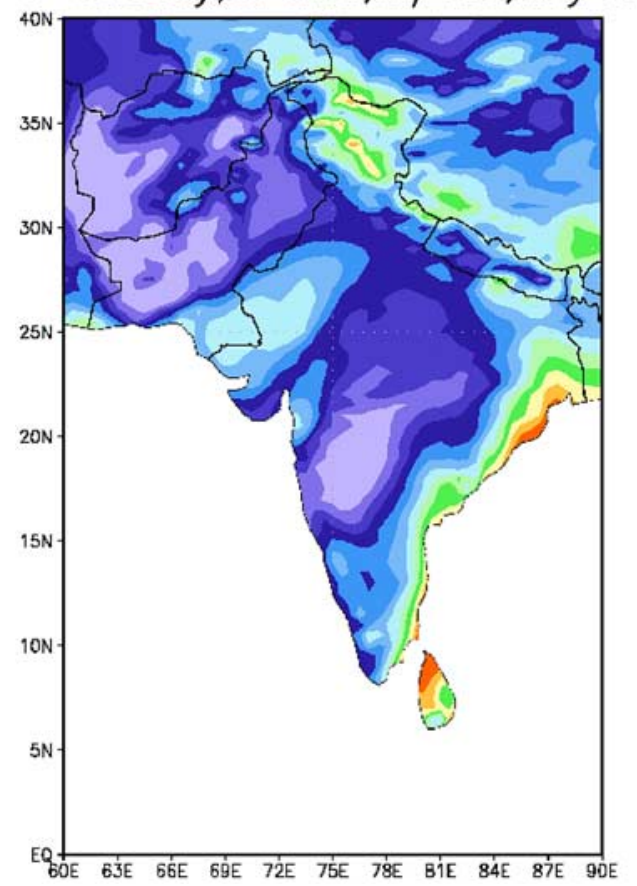

OBSERVATION

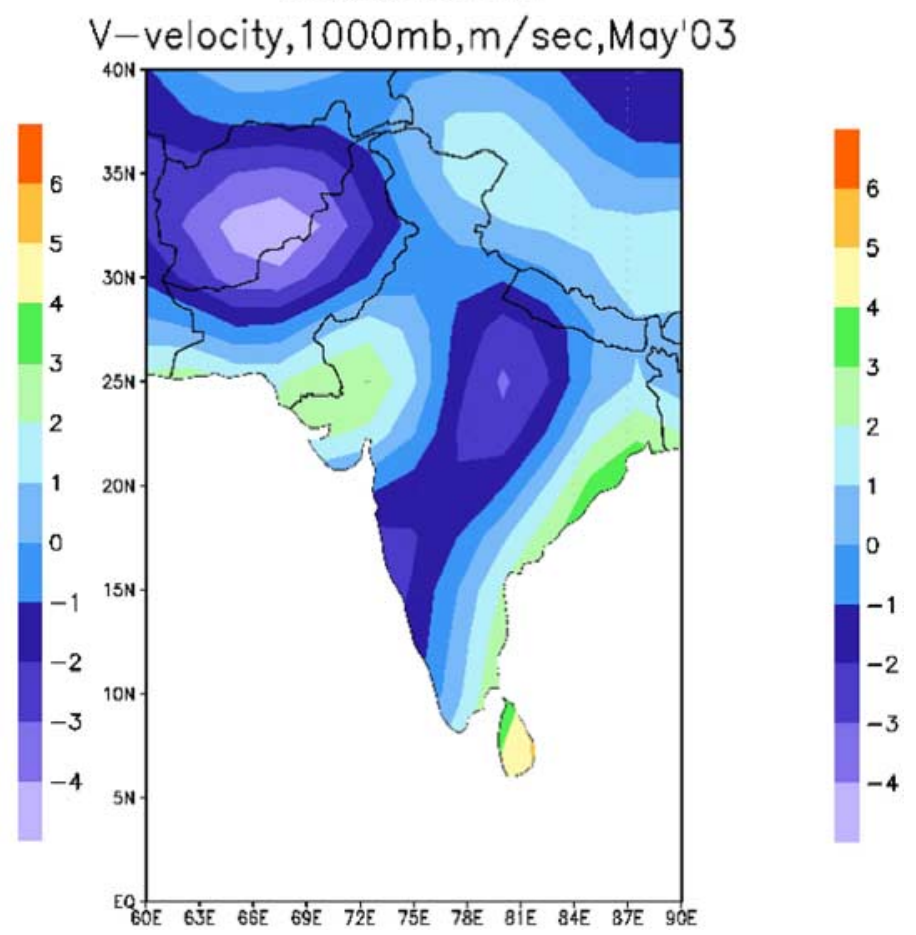

Figure 2b. Same as Figure 2a. but for V-velocity. 
MODEL

$\mathrm{CO}[\mathrm{ppb}], 850 \mathrm{hpa}$, October'2003

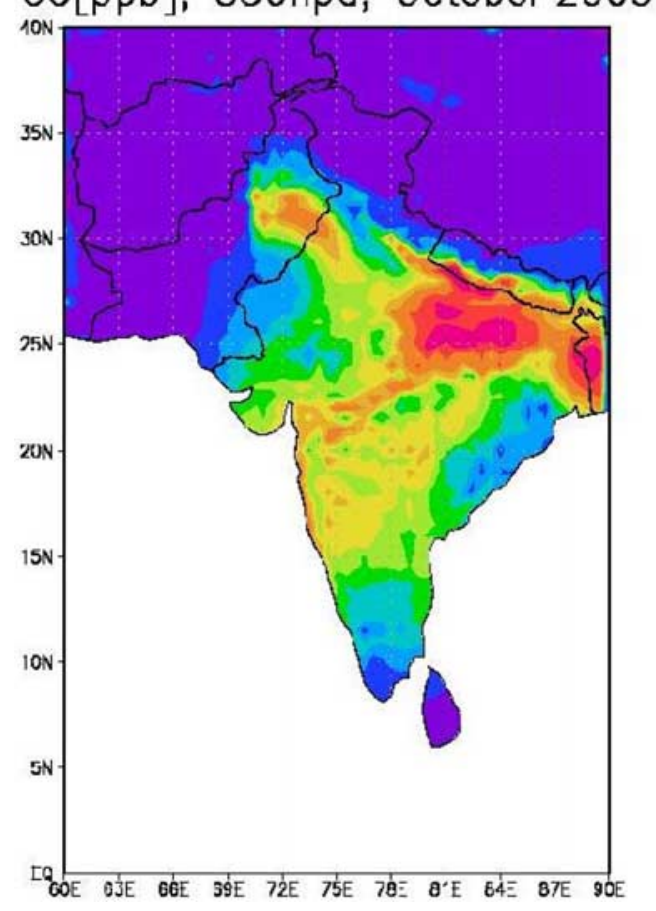

OBSERVATION(MOPITT)

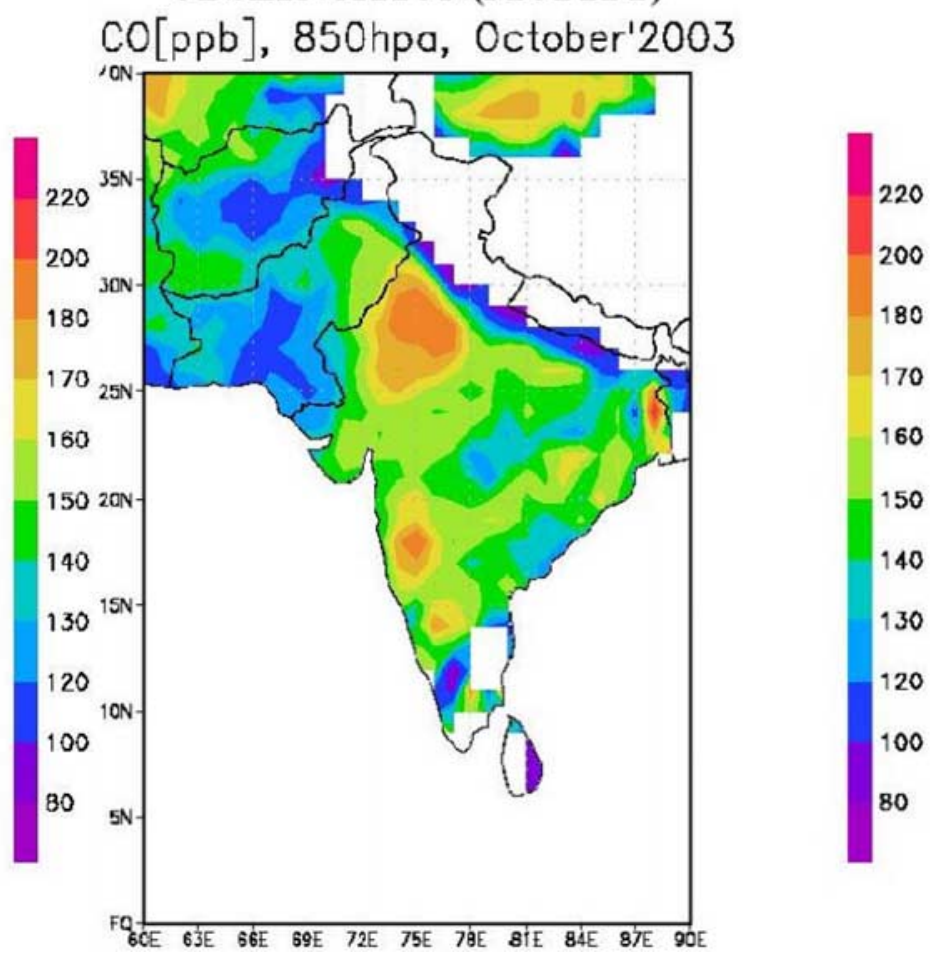

Figure 3. Comparison of monthly mean concentrations for $\mathrm{CO}$ at $850 \mathrm{hPa}$ from model and data obtained from MOPITT for the month of October 2003.

These northeasterly winds can help in transporting the pollutants from the areas where emissions are higher such as the Indo-Gangetic regions toward the remote locations. So along with local emissions whose influence seems to be dominant the regional transport of chemical precursors can play a role in the observed distribution of the chemical species like $\mathrm{CO}$ over India. The maximum $\mathrm{CO}$ values obtained from MOPITT data over the Indian region is around $220 \mathrm{ppb}$. However, the $\mathrm{CO}$ values as obtained from MOPITT do not give the highest concentrations over the Indo-Gangetic plains (IGP). Recent studies have reported that there is a steep gradient in the tracer concentrations over the Indo-Gangetic regions as compared to other parts of India, with much higher values being reported over the IGP area obtained by both observations and modeling studies [Beig and Ali, 2006; Ali et al., 2004]. This striking feature has been simulated well by the model which the data obtained from MOPITT have failed to capture. Keeping this fact in mind we do not expect a point-to-point agreement between the model data and those obtained from MOPITT. Also the data obtained from MOPITT did not seem to be robust and comprehensive with a substantial portion of missing values over the Indian region. All these factors may have led to the gaps in certain regions between the modeled and observed $\mathrm{CO}$ over India. Although we have made the comparison for $\mathrm{CO}$ concentrations between the model and MOPITT data for all the seasons, we chose the month of October for comparison where geographical coverage in MOPITT data is relatively better.

[12] A comparison of the modeled result on the surface concentration of ozone with that of observed data obtained from four different stations available for the Indian region is also made for validation purpose. The location of these four stations is marked in Figure 4. along with other relevant details. The calculated seasonal cycle for ozone is compared with values measured at Pune $\left(18.3^{\circ} \mathrm{N}, 73.6^{\circ} \mathrm{E}\right)$ in Figure 5a. A seasonal maximum of ozone is observed during spring and is well captured by the model. During the winter to spring period, northeasterly winds prevail over Pune which helps in transporting pollutant rich air from the regions where anthropogenic emissions are high. Thus the longrange/regional transport of pollutants can have a significant contribution toward the spring maximum of ozone at Pune as simulated by the model. Also the major industrial areas including some sugar factories are located toward the northeastern side of the receptor site. These sugar industries are operational in the period of October-March when there is a substantial burning of biomass in the form of sugarcane residue. So the northeasterly winds flowing during the winter to spring period can contribute significantly toward the spring maximum of ozone at the receptor site Pune by transporting ozone rich air from these industrial areas. Also the biomass burning is maximum during the dry winter period in the Indian subcontinent region [Galanter et al., 2000] which can result in the regional transport of pollutants to the receptor site. Thus the effects of biomass burning are distinctly visible on the seasonal cycle of ozone at the observational site during this period. The influence of longrange/regional transport is perceived to be more as compared to local photochemical production on the observed spring maximum of ozone at Pune. A seasonal minimum is observed during the period from June-September and is qualitatively 


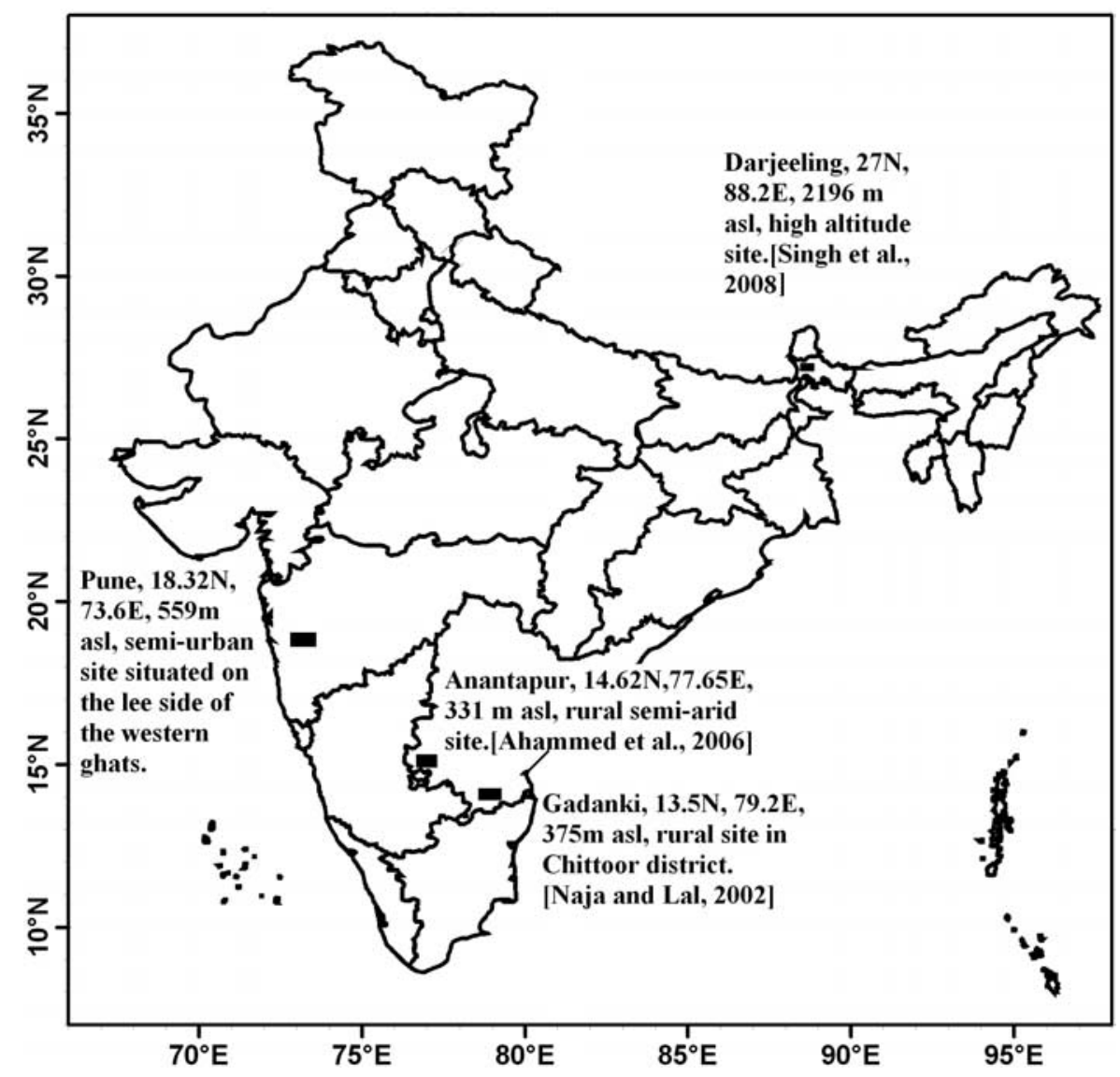

Figure 4. Map of India containing the location and brief description of the four above-mentioned stations.

reproduced by the model although the model over predicts the observed minimum to a large extent. This minimum can be attributed partly to the influences of the southwest monsoon circulation during this period which brings clean marine air containing low concentrations of ozone toward the Indian subcontinent. However, in addition to this, there was excess rainfall during the months of August and September, in the year 2003 at Pune as per the rainfall records [India Metoeorological Department, 2003] and weather was mainly cloudy. This may have resulted in lesser photochemical production of ozone due to decrease in solar intensity and hence the observational values of ozone were found to be very low at Pune during this period. However, in terms of meteorological inputs, since the model was not fed with this kind of a locally confined meteorological phenomena of a point location within the given domain of $0.5^{\circ} \times 0.5^{\circ}$ resolution, it may have overestimated the seasonal minimum of ozone at Pune. During the monsoon period the influence of the local factors on the observed seasonal minimum at Pune seem to be negligible as compared to the southwest monsoon circulation driven convective transport which play a major role in redistributing the pollutants.

[13] The simulated seasonal cycle of ozone is compared with the observed values [Ahammed et al., 2006] at the surface site Anantapur $\left(14.6^{\circ} \mathrm{N}, 77.7^{\circ} \mathrm{E}\right)$ in Figure $5 \mathrm{~b}$. The agreement of observed data and model is reasonably good. The seasonal cycle at this station is very well reproduced by the model. The magnitude of model results is well within the 2-sigma standard deviation of the observed data. The maximum concentration of ozone is observed to be in the period of March-April. The modeled values show a maximum around the month of April. This shows that the influence of dynamics may have strong contribution toward the ozone maximum during the said period. The minimum values of ozone are observed in the monsoon month of August which is also simulated by the model. The low values of ozone during the monsoon months can be attributed to the southwest monsoon circulation which helps in transporting cleaner air from the marine regions toward the Indian landmass. Also owing to cloudy conditions lesser solar insolation may have led to lower photochemical production of ozone during this period.

[14] In Figure 5c we compare the simulated seasonal cycle of ozone with the observed values [Singh et al., 2008] at Darjeeling $\left(27^{\circ} \mathrm{N}, 88.2^{\circ} \mathrm{E}\right)$. Being at an altitude of 2196 masl, the ozone levels would be mainly controlled by horizontal and vertical transport. The observed as well as simulated seasonal values of ozone reach a maximum during the spring period at this site. This seasonal maximum can be contributed by the long-range or regional transport bringing pollutant rich air from the areas with higher levels of pollutants and the downward transport of ozone from higher altitudes. However, in the present study we were unable to quantify the contribution of stratospheric input toward the spring peak of ozone at this site. A seasonal 

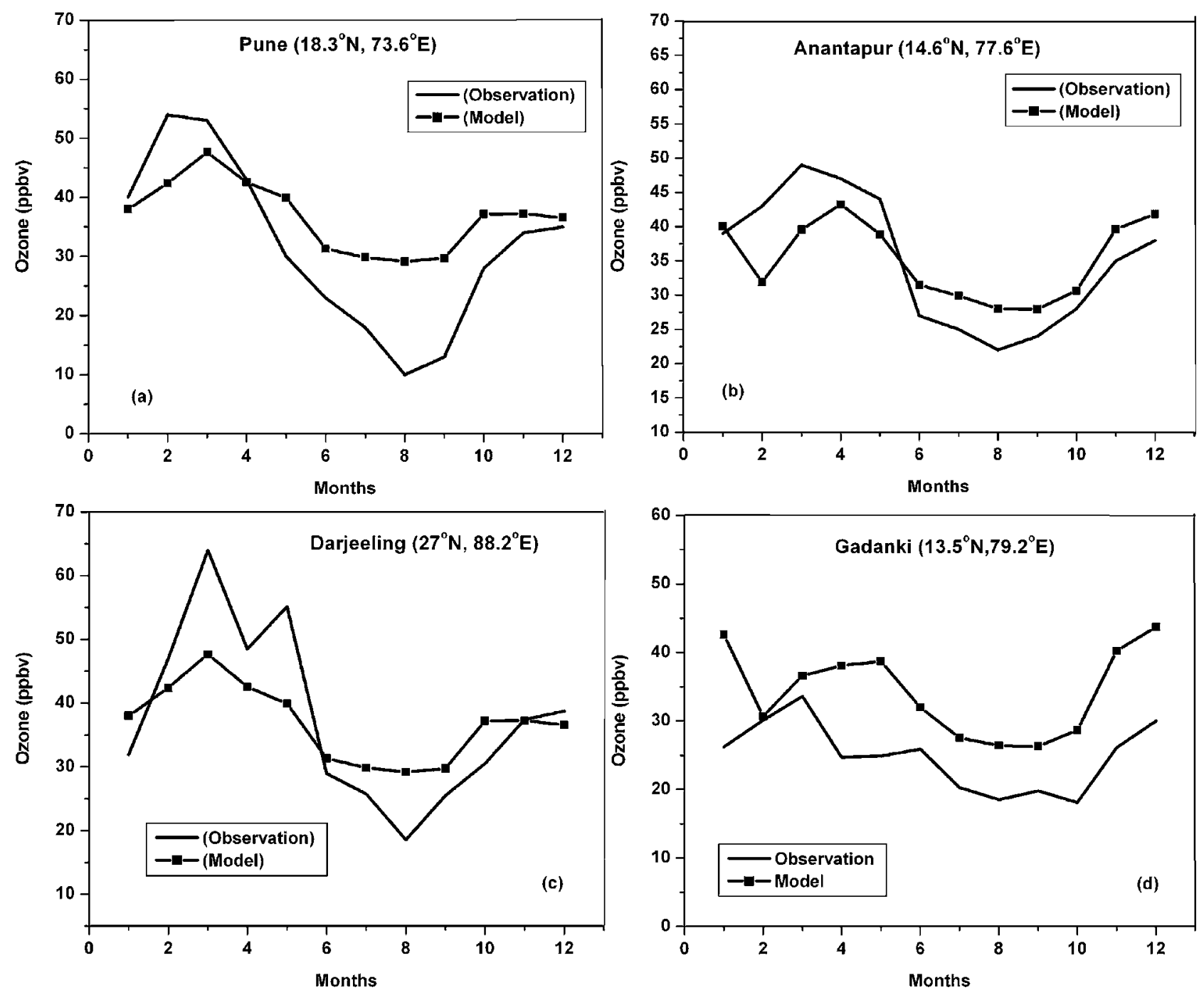

Figure 5. Comparison of seasonal distribution of surface ozone (ppbv) from model and observations at (a) Pune, (b) Anantapur, (c) Darjeeling, and (d) Gadanki.

minimum is observed during the month of August with the overall values being comparatively lower during the monsoon period which is also predicted by the model. This may be a result of the southwest monsoon circulation which helps in transporting cleaner marine air mass toward the Indian region.

[15] The comparison of modeled seasonal cycle of ozone with the observations [Naja and Lal, 2002] from the rural site Gadanki $\left(13.5^{\circ} \mathrm{N}, 79.2^{\circ} \mathrm{E}\right)$ is shown in Figure $5 \mathrm{~d}$. Model is able to reproduce the observations qualitatively well at this site. In Figure 5d we find that the ozone concentrations reach maximum values during the winter/spring period. Being a rural site with very less population, local emissions are lesser at Gadanki. So the regional transport of ozone precursors from nearby cities along with the prevailing biomass burning play a major role on the ozone levels during this period. The general wind pattern over this area varies from northerly to northeasterly from the month of November to March. So there can be influence of longrange/regional transport of polluted air from the northern and northeastern regions during the winter and spring period. The monthly mean concentrations of ozone shows a minimum during the summer monsoon period which can be due to the transport of cleaner air by the prevailing southwesterly winds from the oceanic regions toward the Indian subcontinent.

[16] In Figures $6 \mathrm{a}, 6 \mathrm{~b}$ and $6 \mathrm{c}$ we compare the simulated distributions of monthly mean $\mathrm{CO}, \mathrm{NO}_{\mathrm{x}}$ and Ozone obtained from REMO-CTM with the results from the global model MOZART for the month of October. In Figures 6a, $6 \mathrm{~b}$ and $6 \mathrm{c}$ we observe that the overall pattern in the simulated distributions of the species between the global and the regional model appear to be similar, although the values obtained from the global model are higher compared to the regional model. However, the resolution of the global model is almost three times as that of the regional model. Owing to this coarser resolution, MOZART is not able to reproduce properly the cellular spatial structures of the trace species over the different parts of India which is well resolved by the regional model. We also find that the overall pattern of the calculated distributions of $\mathrm{CO}$ and $\mathrm{NO}_{\mathrm{x}}$ from the regional model to be more closer with the results 
REMO-CTM
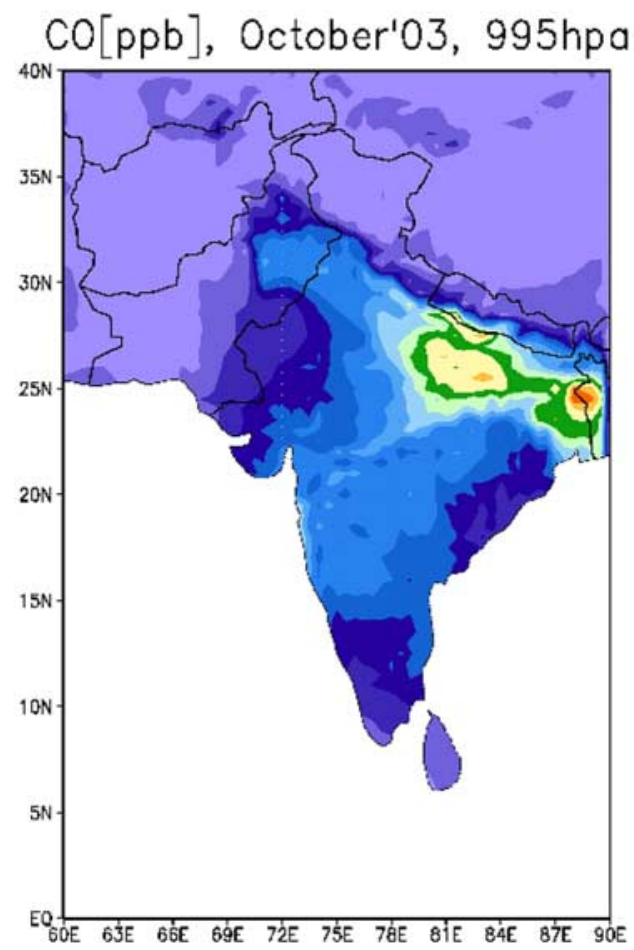

MOZART

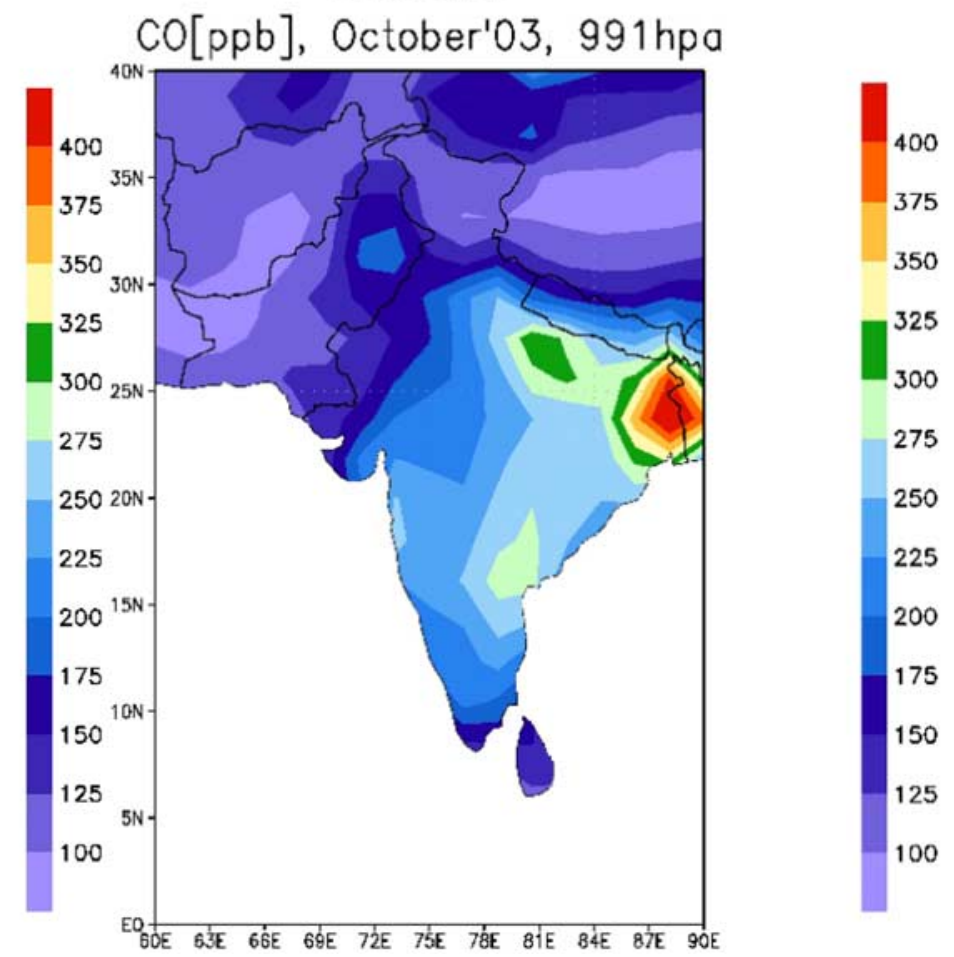

Figure 6a. Comparison of monthly mean concentrations of $\mathrm{CO}$ during the month of October 2003 from the global model MOZART and the regional model REMO-CTM.

obtained from the global model as compared to ozone. This may be due to the difficulty in a global model to simulate the nonlinear chemistry involved in the photochemical production of ozone from $\mathrm{NO}_{\mathrm{x}}$ and hydrocarbons [Bey et al., 2001]. Earlier modeling studies [Wild et al., 2006; Jang et al.,1995a] indicate that spatial scales of less than $20 \mathrm{~km}$ may be required for accurately modeling ozone production. In Figure 6a we find that the monthly mean values of $\mathrm{CO}$
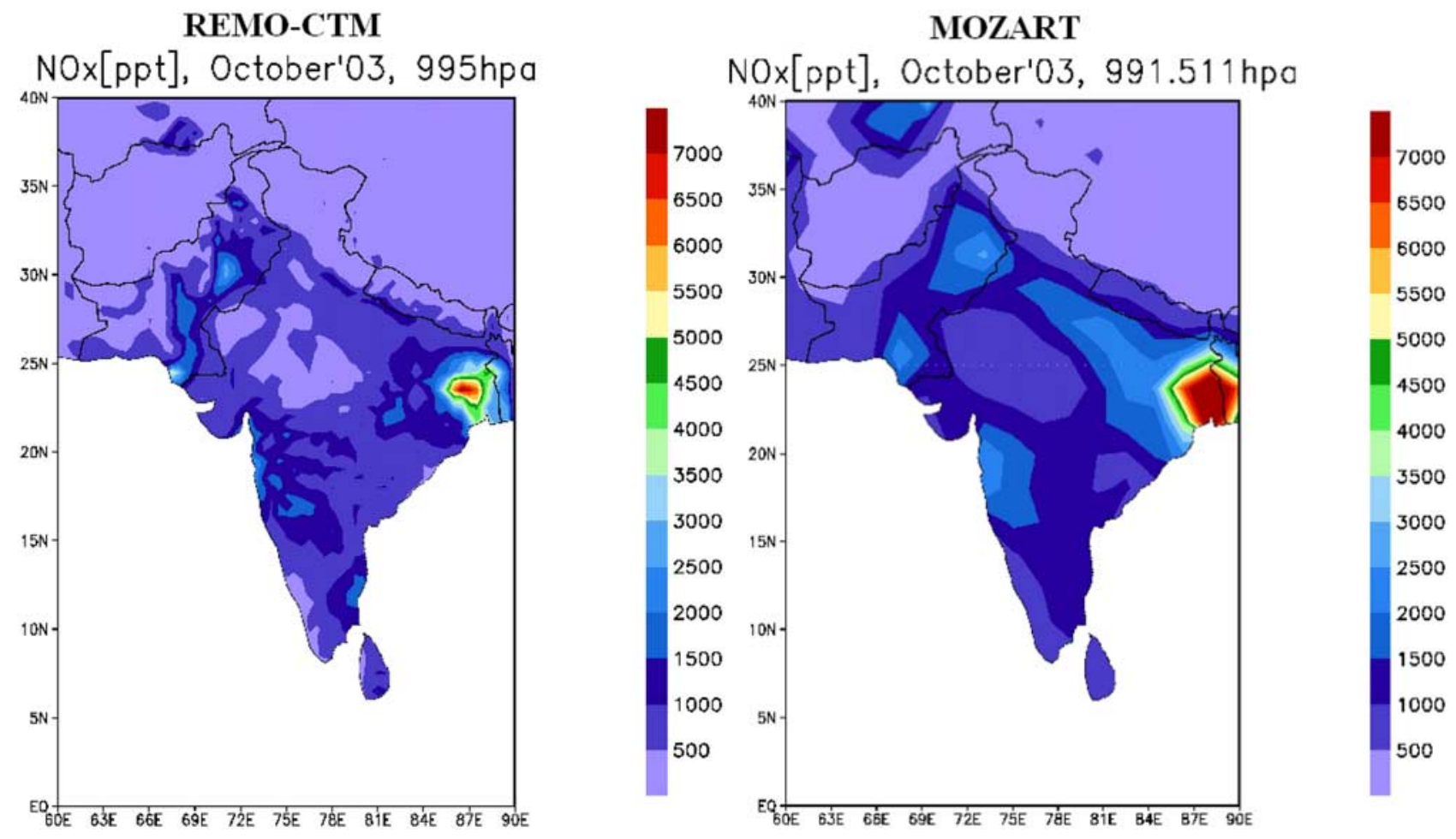

Figure 6b. Same as Figure 6a but for $\mathrm{NO}_{\mathrm{x}}$. 

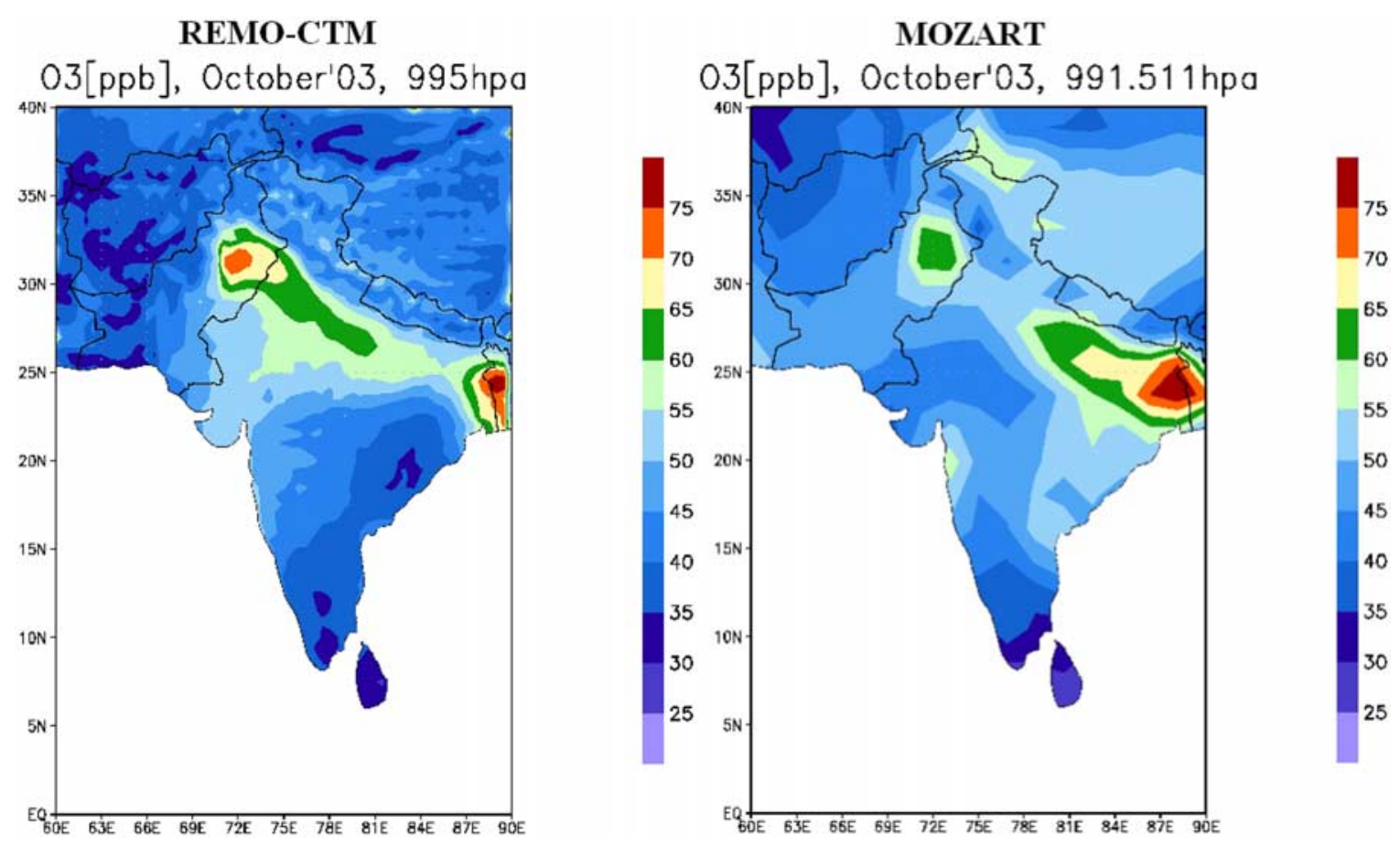

Figure 6c. Same as Figure 6a but for ozone.

are in the range of $175-275 \mathrm{ppb}$ over most parts of India. In the Indo-Gangetic plains where the emission intensities are more, the concentrations are on the higher side with the highest values reaching around $400 \mathrm{ppb}$ in the same region. In Figure $6 \mathrm{~b}$ we observe that in most of the regions of India the monthly mean concentrations of $\mathrm{NO}_{\mathrm{x}}$ are in the range of $0.5-1.5 \mathrm{ppb}$. In some parts of southwest India and the Indo-Gangetic regions which are more emission-prone, the concentrations are on the higher side and the maximum concentrations are around $7 \mathrm{ppb}$ over the gangetic West Bengal. In Figure $6 \mathrm{c}$ it is seen that the monthly average concentration of Ozone over the Indian region lies in the range of 35-55 ppb. The values over the Indo-Gangetic areas are comparatively higher and the maximum concentrations are seen to be around $75 \mathrm{ppb}$ in the gangetic West Bengal.

\section{Results and Discussions}

[17] In this section, we provide the seasonal distribution of surface ozone and its precursors during the premonsoon, monsoon and postmonsoon seasons over India. Apart from the emissions of secondary pollutants, meteorological processes play an important role in the distribution of boundary layer ozone and its precursors. We choose the months of May, July and October to be representative month for premonsoon, monsoon and postmonsoon seasons over the Indian region. The monthly mean variations for ozone, $\mathrm{CO}$ and $\mathrm{NO}_{\mathrm{x}}$ at surface during the months of May, July and October are shown in the Figures 7, 8 and 9 respectively.

[18] The premonsoon season in India is a hot season characterized by high temperatures due to intense solar radiation. This can help in providing stable and stagnant situations favorable for higher concentrations of ozone. Also the emissions of ozone precursors from biomass burning are more prevalent in the dry season over India.
The wind pattern changes from northeasterly to southwesterly over the Indian region during the month of May. In Figure 7 we find that in most of the areas over India, the concentration of ozone is in the range of $30-48 \mathrm{ppb}$. Higher concentrations of ozone are seen in some parts of southwest India where the anthropogenic emissions are on the higher side [Dalvi et al., 2006]. The highest concentration for ozone in this month is around $55 \mathrm{ppb}$ over the Indo-Gangetic regions. The concentration of CO in most parts of India is within $100-170 \mathrm{ppb}$ range. The concentrations are higher in some parts of southwest and southeast India as compared to the values of $\mathrm{CO}$ in the extreme northern Indian regions and many areas of central India where the anthropogenic emissions are lesser. The $\mathrm{CO}$ mixing ratios reaches a maximum of $375 \mathrm{ppb}$ in the Indo-Gangetic plains during the month of May and is much higher as compared to the rest of India. The simulated concentrations of $\mathrm{NO}_{\mathrm{x}}$ vary in the range of $0.5-3 \mathrm{ppb}$ in major portions of India. In some parts of southwestern India the concentrations are on the higher side and the values are lower over the extreme northern Indian regions. The maximum concentration of $\mathrm{NO}_{\mathrm{x}}$ is around $9 \mathrm{ppb}$ over the Gangetic West Bengal during this period. In the premonsoon months, low-level troughs and associated cyclonic circulation are prevalent over the Indo-Gangetic regions. This helps in mild convergence of winds along this area resulting in confinement of ozone and its precursors which enhances the concentrations of these tracers.

[19] In Figure 8 we notice that during the month of July, the calculated magnitude of concentrations of ozone and its precursors are lesser over different parts of India as compared to the premonsoon and postmonsoon months. This is, in general, a result of the southwest monsoon circulation when southwesterly winds tend to bring cleaner air from the oceanic regions over the Indian landmasses. Also owing to 


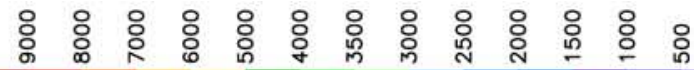
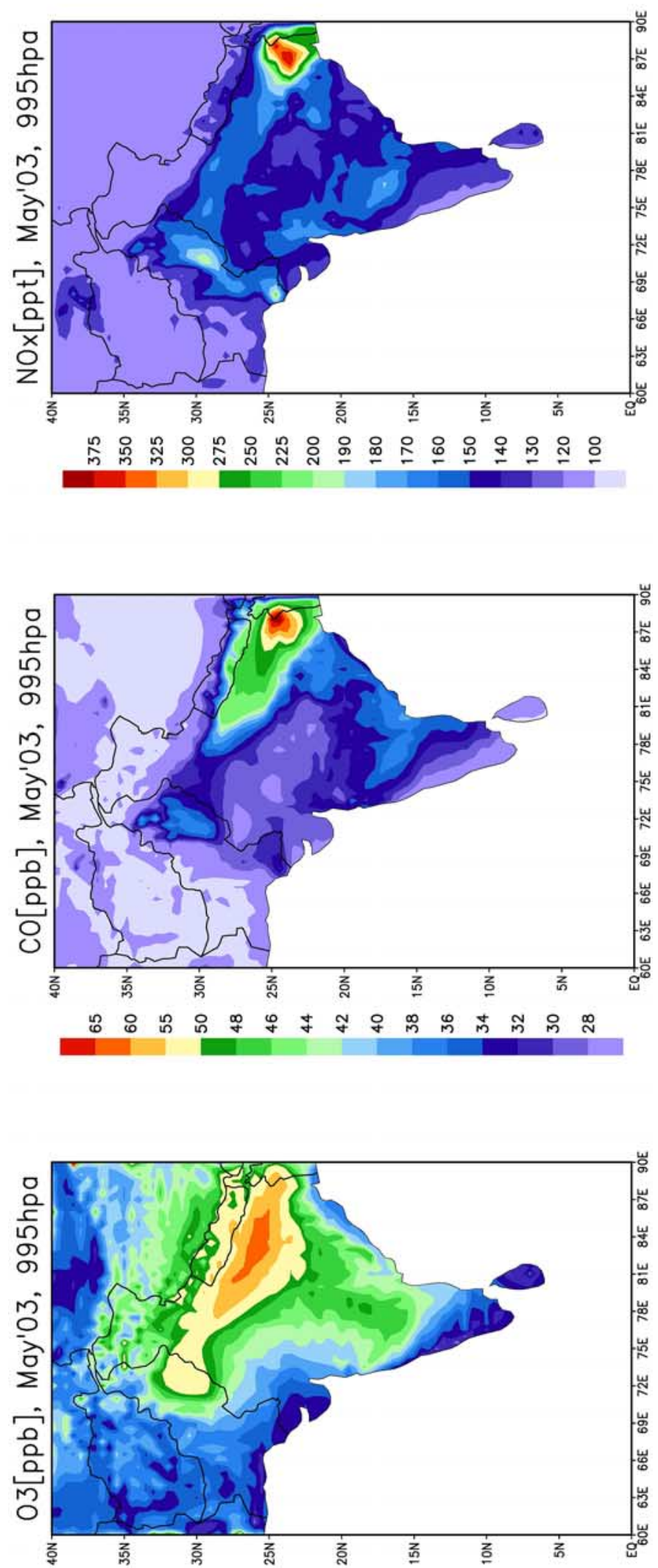

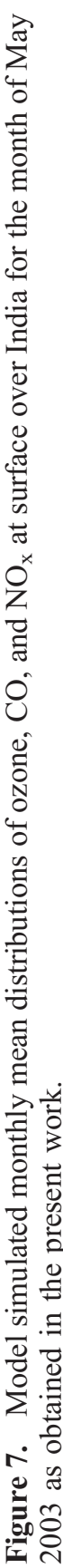



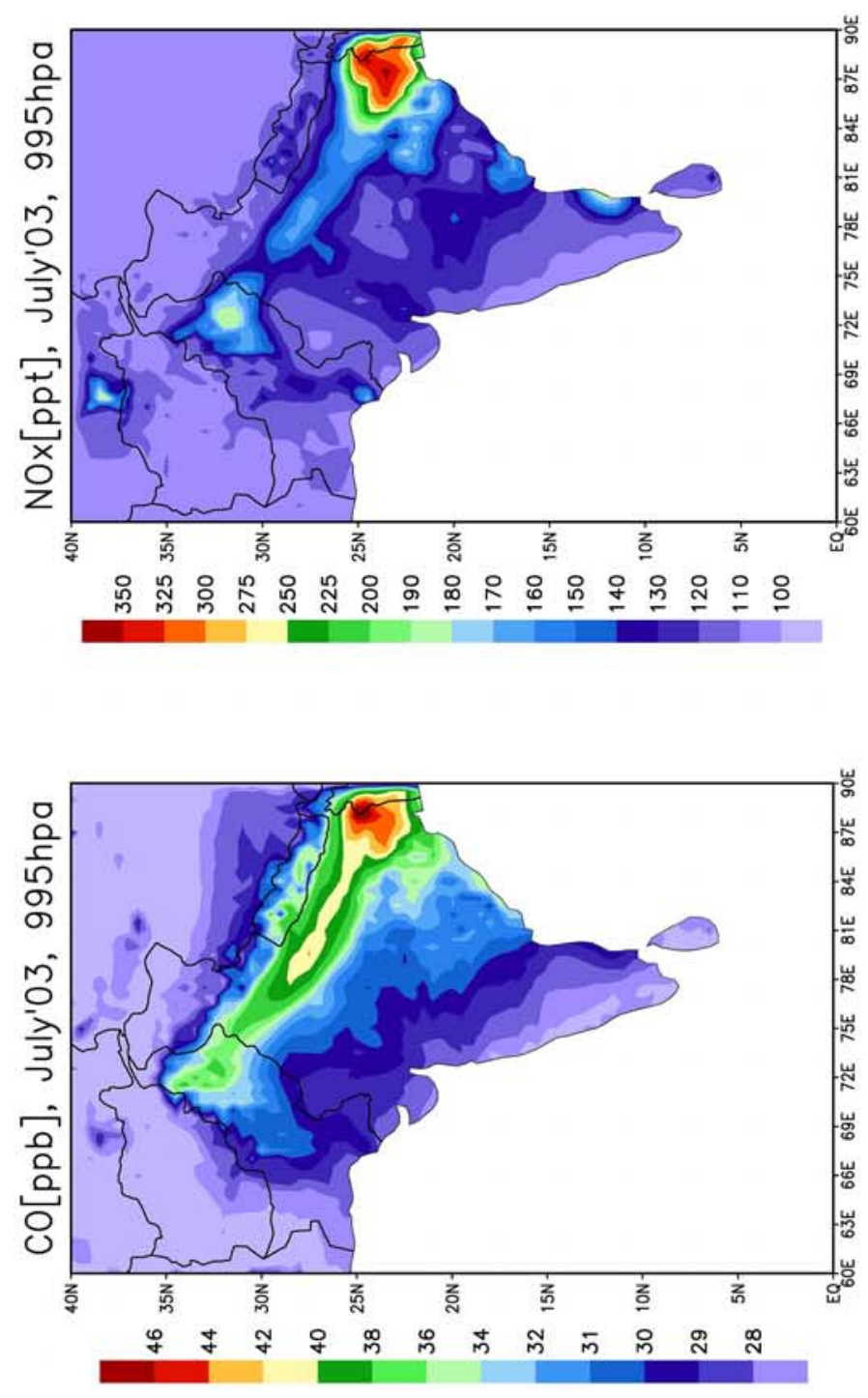

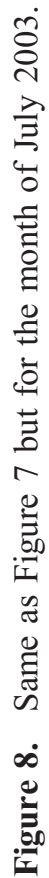

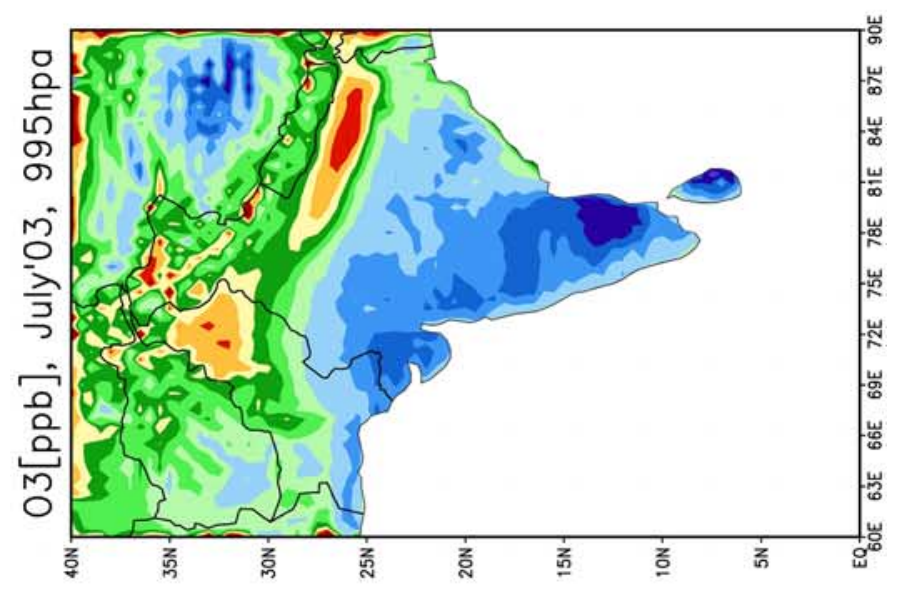




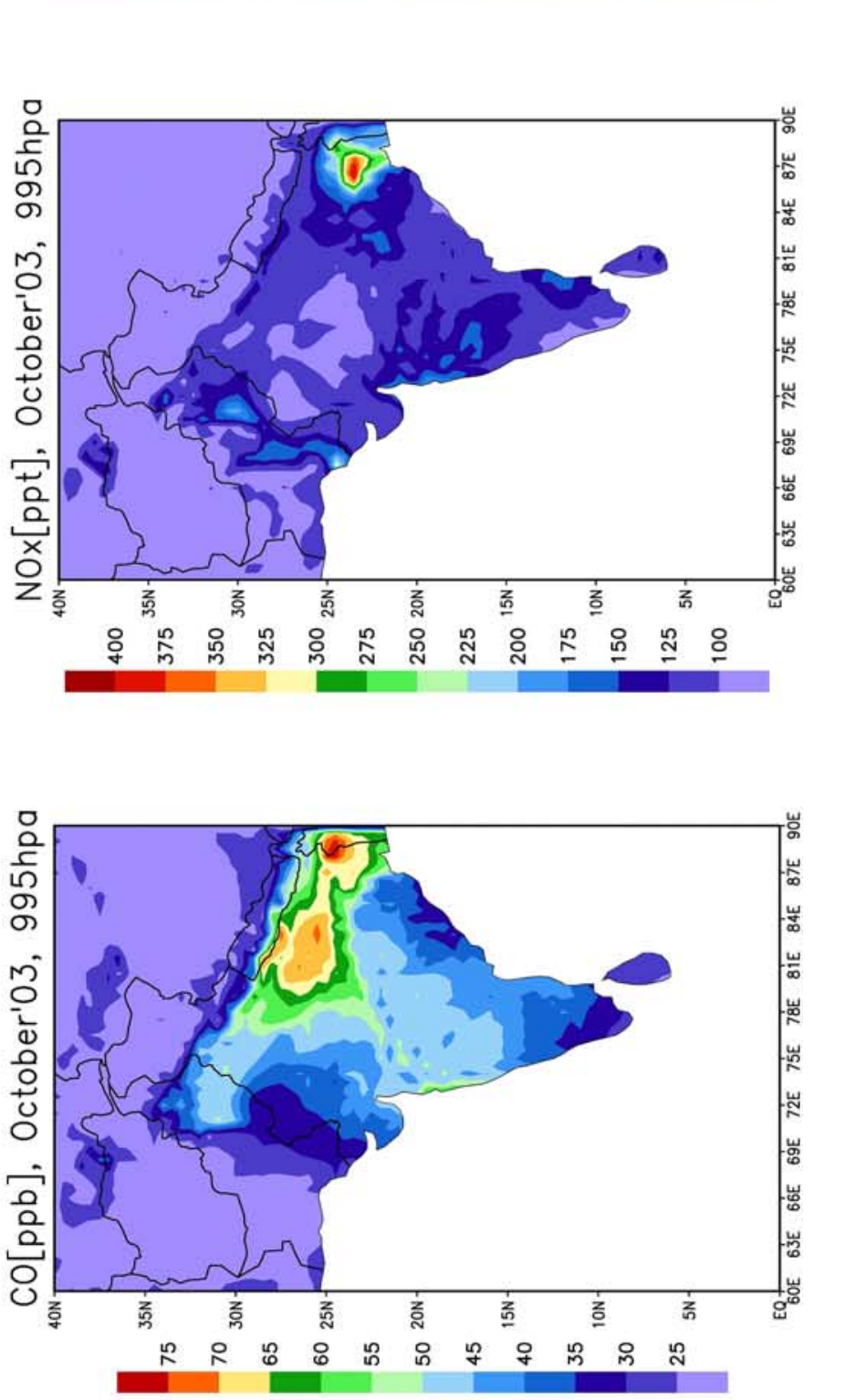

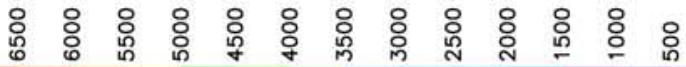

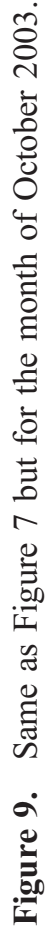

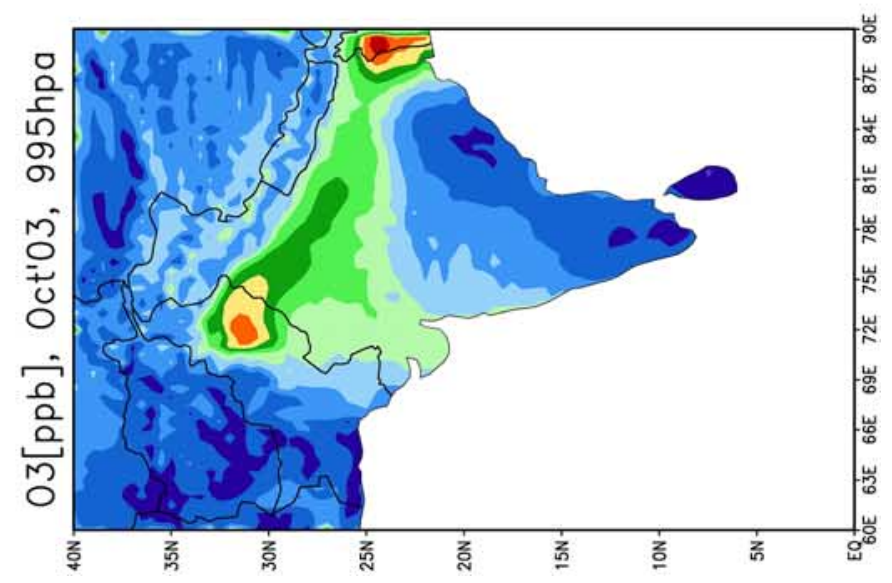


the cloudy conditions during monsoon, solar intensity is reduced and less photochemical production occurs. The effect of monsoon circulation driven transport on the concentrations of the tracers appears to be more in this period as compared to local factors. In majority of the Indian regions, concentration of ozone varies in the range of $28-34 \mathrm{ppb}$ during this period. The predicted value for $\mathrm{CO}$ during this period is minimum and lies within the range of $100-$ $160 \mathrm{ppb}$ in most parts of India. This is mainly due to the effect of southeasterly winds prevailing over the Indian region during the monsoon period which transports cleaner air from the oceanic regions toward the Indian landmass. In addition to this, recent studies [Li et al., 2005] have shown that carbon monoxide transported upward by the deep convection associated with the summer monsoon is trapped within the monsoon anticyclone in the upper troposphere. Recent satellite observations also have highlighted the strong isolation of carbon monoxide within the monsoon anticyclone, extending into the lower stratosphere [Fu et al., 2006; Park et al., 2007]. So a combination of both longrange transport of cleaner marine air and vertical transport driven by deep convection can be contributing toward the monsoon minimum of Carbon Monoxide over the Indian subcontinent. The distributions of $\mathrm{NO}_{\mathrm{x}}$ over India during this period also shows lower concentrations of around $0.5-$ $1.5 \mathrm{ppb}$ in many parts of India which may be attributed to the monsoon circulations and associated washout. However, the distributions of ozone and its precursors over the IndoGangetic regions are substantially higher than the rest of India during this period. Owing to the convergence of northerly winds driven by the monsoon and the southerly maritime winds, this region appears to be acting as an area of convergence wherein the pollutants tends to get confined. This convergence is also driven by the continental part of the tropical convergence zone (CTCZ) which consists of a low-pressure area extending from the Bay of Bengal throughout the Indo-Gangetic belt till the extreme northwestern sides of India. The maximum value for ozone during this month happen to be over the Indo-Gangetic plains and is around $44 \mathrm{ppb}$. In the same region, the concentrations for $\mathrm{CO}$ reaches a maximum of $350 \mathrm{ppb}$ and the highest concentrations for $\mathrm{NO}_{\mathrm{x}}$ is found to be around $8 \mathrm{ppb}$.

[20] As seen in Figure 9 that during the postmonsoon month of October, ozone seems to be varying in the range of $30-50 \mathrm{ppb}$ in major parts of India with higher values toward the southwestern side. Owing to less solar intensity and more humid conditions prevailing during this season the overall concentrations of ozone over most parts of India during this month is found to be lesser than the premonsoon month of May. The highest concentration of ozone are found to be around $75 \mathrm{ppb}$ over the gangetic West Bengal. The calculated value of $\mathrm{CO}$ varies in the range of $100-$ $225 \mathrm{ppb}$ during this postmonsoon month in most of the Indian regions. Overall the concentration of $\mathrm{CO}$ is found to be higher over the different parts of India during this period as compared to the premonsoon month of May. This can be due to the temperature inversions occurring at low level during this period which helps in accumulation and buildup of surface $\mathrm{CO}$. Also the postmonsoon northeasterly winds tend to transfer the pollutants from the areas with higher emission intensity toward the remote and coastal regions over India. The effect of regional transport is more prominent in case of $\mathrm{CO}$ as compared to ozone on account of the lower photochemical production of ozone in this period as well as lesser lifetime as compared to CO. Both the effects of local emissions as well as transport which is not strong, seem to effect the concentrations of these pollutants over India during this period. The simulated values of $\mathrm{CO}$ attain a maximum of $400 \mathrm{ppb}$ in the Indo-Gangetic region in this month. During this period the modeled values of $\mathrm{NO}_{\mathrm{x}}$ seem to be in a much lower range of $0.5-2 \mathrm{ppb}$ as compared with the month of May in many parts of India. Being a shortlived species $\mathrm{NO}_{\mathrm{x}}$ is mostly consumed close to the emission sources and is unable to survive transport. Owing to this fact the concentrations of $\mathrm{NO}_{\mathrm{x}}$ are mostly seen to be higher near the areas with higher emission levels. The maximum concentration of $\mathrm{NO}_{\mathrm{x}}$ is found to be around $6.5 \mathrm{ppb}$ over the Gangetic West Bengal in this month. During the postmonsoon period the occurrences of western disturbances are frequent over India. The associated northwesterly winds help in bringing cold wave conditions over the northern parts of India. This lowers the ambient temperature and thereby brings down the temperature inversion to a lower level which enhances the concentration of ozone and its precursors in the Indo-Gangetic regions. During the winter month of December, we find that the maximum concentration of ozone is around $75 \mathrm{ppb}$ over the gangetic West Bengal. In major parts of India, ozone concentration lies in the range of $45-52 \mathrm{ppb}$ which is quite lesser as compared to the ozone values over the Indo-Gangetic plains. The concentration of CO varies in the range of 200-300 ppb over most areas of India. The highest concentration of $\mathrm{CO}$ is found to be around $450 \mathrm{ppb}$ over the Indo-Gangetic regions where the overall $\mathrm{CO}$ concentration is higher as compared to the remaining parts of India. The predicted values for $\mathrm{NO}_{\mathrm{x}}$ lies in the range of $0.25-1.0 \mathrm{ppt}$ over major parts of India and the maximum values are found to be around $5 \mathrm{ppt}$ over the gangetic plains of West Bengal. Higher concentrations of $\mathrm{NO}_{\mathrm{x}}$ are seen in some parts of southwestern India.

[21] During the spring month of March, we find that the concentration of Ozone is in the range of 40-50 ppb in most parts of India. The ozone values peaks at around $75 \mathrm{ppb}$ in some parts of the Indo-Gangetic regions where the overall concentrations are comparatively higher than the remaining parts of India. Higher concentrations are also seen in some areas of southwest India. The calculated value of $\mathrm{CO}$ is found to be in the range of $120-210 \mathrm{ppb}$ in major parts of India. The CO values maximizes at around $390 \mathrm{ppb}$ in the eastern parts of the Indo-Gangetic plains. In some areas of southwest India the concentrations are found to be higher. The simulated concentration of $\mathrm{NO}_{\mathrm{x}}$ varies in the range of $0.5-1.5 \mathrm{ppt}$ in most of the areas of India. The maximum values of $7 \mathrm{ppt}$ are found to be in some parts of the Indo-Gangetic plains toward the eastern side. The concentrations are also found to be higher in some areas of southwest India. The winter-spring period is a dry period when biomass burning is prevalent in some parts of India leading to higher emission levels of ozone precursors. During this period the winds are northerly to northeasterly over the Indian region which can help in transporting the tracers from the pollutant rich areas toward other parts of India. Also the overall conditions are mostly calm and quiet 
which can provide a stable situation for the photochemical production of ozone. So both long-range/regional transport and local photochemical production may contribute toward the concentrations of ozone during this period.

[22] For all the seasons, the concentration of ozone and its precursors over the Indo-Gangetic region appears to be much higher than the remaining parts of India. The emission intensities of ozone precursors are quite higher over the densely populated Indo-Gangetic plain which has a significant proportion of rural population. Since the formation of ozone is nonlinear with respect to its precursors, there is no direct correlation between the emission intensities of ozone precursors and ozone concentrations. However, higher concentrations of ozone are observed where the emission intensities of ozone precursors tends to be high up to a certain limit, since an optimum proportion of ozone precursors is favorable for the nonlinear photochemical production of ozone. Moreover, owing to favorable synoptic weather conditions like monsoon circulation and orographic features, this region is prone to confinement of the emitted tracers and thereby enhancing the photochemical production of ozone to a great extent as compared to the other parts of India.

\section{Conclusions}

[23] The seasonal distribution of ozone and its precursors has been presented in this paper over the Indian tropical region using the regional chemistry transport model. The general distributions of ozone and its related species during the premonsoon, monsoon and postmonsoon seasons over India is found to be closely related with the prevailing synoptic weather conditions and associated long-range/ regional transport along with anthropogenic activities. The model simulates the typical patterns of higher concentrations of ozone and its precursors over the densely populated Indo-Gangetic plains of India which tends to confine the tracers owing to its favorable synoptic weather conditions and orographic features. The model is able to capture the variability in the precipitation pattern over India to a reasonable extent which is an essential factor for simulating such key species in the atmosphere. The wind fields are simulated by the model both in magnitude and direction to a reasonable extent. The seasonal pattern of observed ozone at several observational sites has been reproduced by the model qualitatively very well. The quantitative agreement is also found to be reasonable at some locations. At the receptor location Pune the model overestimates the minimum which is mainly attributed to the sudden local meteorological conditions developed at the receptor site. The locations of the highest concentrations of $\mathrm{CO}$ as seen from the satellite data do not exactly match with the modeled value and there are some data gaps between the modeled and observed $\mathrm{CO}$. The overall pattern of the distributions of ozone, $\mathrm{CO}$ and $\mathrm{NO}_{\mathrm{x}}$ appear to be similar in comparison with the results from the global model. However, the values obtained from the global model are higher and the global model is unable to simulate properly the cellular spatial structure of these species.

[24] Acknowledgments. We thank the director of IITM for his encouragement in this work. We wish to express our thanks to the NOAA/Climate Prediction Center's FEWS-NET group sponsored by USAID for the data obtained from their website at http://www.cpc.ncep. noaa.gov/. We are thankful to the NCEP/NCAR Reanalysis Project (CDAS) for the data available at the website http://ingrid.ldgo.columbia.edu/SOURCES/.NOAA/.NCEP-NCAR/.CDAS-1/.

\section{References}

Ahammed, Y., et al. (2006), Seasonal variation of the surface ozone and its precursor gases during 2001-2003, measured at Anantapur $\left(14.62^{\circ} \mathrm{N}\right)$, a semi-arid site in India, Atmos. Res., 80, 151-164, doi:10.1016/ j.atmosres.2005.07.002.

Ali, K., et al. (2004), Surface ozone measurements over Himalayan region and Delhi, north India, Ind. J. Radio Space Phys., 33, 391-398.

Beig, G., and K. Ali (2006), Behavior of boundary layer ozone and its precursors over a great alluvial plain of the world: Indo-Gangetic Plains, Geophys. Res. Lett., 33, L24813, doi:10.1029/2006GL028352.

Beig, G., and G. P. Brasseur (2006), Influence of anthropogenic emissions on tropospheric ozone and its precursors over the Indian tropical region during a Monsoon, Geophys. Res. Lett., 33, L07808, doi:10.1029/ 2005 GL 024949.

Beig, G., et al. (2007), Simultaneous measurements of ozone and its precursors on a diurnal scale at a semi urban site in India, J. Atmos. Chem., 7(3), 239-253, doi:10.1007/s10874-007-9068-8.

Bey, I., D. J. Jacob, R. M. Yantosca, J. A. Logan, B. D. Field, A. M. Fiore, Q. Li, H. Y. Liu, L. J. Mickley, and M. G. Schultz (2001), Global modeling of tropospheric chemistry with assimilated meteorology: Model description and evaluation, J. Geophys. Res., 106, 23,073-23,095 doi:10.1029/2001JD000807.

Brasseur, G., et al. (2006), Impact of climate change on the future chemical composition of the global troposphere, J. Clim., 19(16), 3932-3951, doi:10.1175/JCLI3832.1.

Dalvi, M., G. Beig, U. Patil, A. Kaginalkar, C. Sharma, and A. P. Mitra (2006), A GIS based methodology for gridding large scale emission inventories: Application to carbon-monoxide emissions over Indian region, Atmos. Environ., 40, 2995-3007, doi:10.1016/j.atmosenv. 2006.01.013.

$\mathrm{Fu}, \mathrm{R}$., et al. (2006), Short circuit of water vapor and polluted air to the global stratosphere by convective transport over the Tibetan Plateau, Proc. Natl. Acad. Sci. U. S. A., 103, 5664-5669, doi:10.1073/ pnas.0601584103.

Galanter, M., H. Levy, and G. Carmichael (2000), Impacts of biomass burning on tropospheric $\mathrm{CO}, \mathrm{NO}_{\mathrm{x}}$, and $\mathrm{O}_{3}$, J. Geophys. Res., 105 , 6633-6653, doi:10.1029/1999JD901113.

Granier, C., and G. P. Brasseur (2003), The impact of road traffic on global tropospheric ozone, Geophys. Res. Lett., 30(2), 1086, doi:10.1029/ 2002GL015972.

India Meteorological Department (2003), Indian daily weather report, report, New Delhi.

Jacob, D., et al. (2001), A comprehensive model intercomparison study investigating the water budget during the PIDCAP period, Meteorol. Atmos. Phys., 77(1-4), 19-44, doi:10.1007/s007030170015.

Jacob, D., et al. (2007), An inter-comparison of regional climate models for Europe: Design of the experiments and model performance, Clim. Change, 81, doi:10.1007/s10584-006-9213-4.

Jang, J. C., et al. (1995a), Sensitivity of ozone to model grid resolution: Part 1. Application of high-resolution regional acid deposition model, Atmos. Environ., 29, 3085-3100, doi:10.1016/1352-2310(95)00118-I.

Khemani, L. T., et al. (1995), Study of surface ozone behavior at urban and forested sites in India, Atmos. Environ., 29, 2021-2024, doi:10.1016/ 1352-2310(94)00293-T.

Lal, S., M. Naja, and B. H. Subbaraya (2000), Seasonal variations in surface ozone and its precursors over an urban site in India, Atmos. Environ. 34, 2713-2724, doi:10.1016/S1352-2310(99)00510-5.

Langmann, B. (2000), Numerical modelling of regional scale transport and photochemistry directly together with meteorological processes, Atmos. Environ., 34, 3585-3598, doi:10.1016/S1352-2310(00)00114-X.

Lelieveld, J., et al. (2001), The Indian Ocean Experiment: Widespread air pollution from South and Southeast, Asia Science, 291(5506), 10311036, doi: $10.1126 /$ science. 1057103 .

Li, Q., et al. (2005), Trapping of Asian pollution by the Tibetan anticyclone: A global CTM simulation compared with EOS MLS observations, Geophys. Res. Lett., 32, L14826, doi:10.1029/2005GL022762.

Mittal, L. M., et al. (2007), Surface ozone in the Indian region, Atmos. Environ., 41, 6572-6584, doi:10.1016/j.atmosenv.2007.04.035.

Naja, M., and S. Lal (2002), Surface ozone and precursor gases at Gadanki $\left(13.5^{\circ} \mathrm{N}, 79.2^{\circ} \mathrm{E}\right)$, a tropical rural site in India, J. Geophys. Res., 107(D14), 4197, doi:10.1029/2001JD000357.

Naja, M., S. Lal, and D. Chand (2003), Diurnal and seasonal variabilities in surface ozone at a high altitude site $\mathrm{Mt} \mathrm{Abu}\left(24.6^{\circ} \mathrm{N}, 72.7^{\circ} \mathrm{E}, 1680 \mathrm{~m}\right.$ asl $)$ in India, Atmos. Environ., 37, 4205-4215, doi:10.1016/S13522310(03)00565-X. 
Olivier, J., et al. (2003), Present and future surface emissions of atmospheric compounds, POET Rep. 2, Eur. Union, Brussels.

Park, M., et al. (2007), Chemical isolation in the Asian monsoon anticyclone observed in Atmospheric Chemistry Experiment (ACE-FTS) data, Atmos. Chem. Phys., 7, 13839-13,860.

Prather, M., et al. (2003), Fresh air in the 21st Century?, Geophys. Res. Lett., 30(2), 1100, doi:10.1029/2002GL016285.

Ramanathan, V., et al. (2001), The Indian Ocean Experiment: An integrated analysis of the climate forcing and effects of the great Indo-Asian haze, J Geophys. Res., 106, 28,371-28,398, doi:10.1029/2001JD900133.

Saraf, N., G. Beig, and M. Schultz (2003), Tropospheric distribution of ozone and its precursors over the tropical Indian ocean, J. Geophys. Res., 108(D20), 4636, doi:10.1029/2003JD003521.
Singh, A., et al. (2008), Study of surface ozone behavior at Darjeeling $\left(27.01^{\circ} \mathrm{N}, 88.25^{\circ} \mathrm{E}\right)$, a site of the Eastern Himalayas, Atmos. Environ. in press.

Wild, O., et al. (2006), Global tropospheric ozone modelling: Quantifying errors due to grid resolution, J. Geophys. Res., 111, D11305, doi:10.1029/ 2005JD006605.

G. Beig and S. Roy, Physical Meteorology and Aerology Division, Indian Institute of Tropical Meteorology, Dr. Homi Bhabha Road, Pune 411008, India. (beig@tropmet.res.in)

D. Jacob, Regional Climate Modeling Group, Atmosphere in the Earth System, Max-Planck-Institute for Meteorology, D-20146 Hamburg, Germany. 